Parrack, C, Flinn, B and Passey, M (2014) Getting the Message Across for Safer Self-Recovery in Post-Disaster Shelter. Open House International, 39 (3)

This version is available: https://radar.brookes.ac.uk/radar/items/b0bd437a-4aec-4849-a849-fb3f8fc2f0ce/1/

Available on RADAR: 17 November 2014

Copyright $\odot$ and Moral Rights are retained by the author(s) and/ or other copyright owners. A copy can be downloaded for personal non-commercial research or study, without prior permission or charge. This item cannot be reproduced or quoted extensively from without first obtaining permission in writing from the copyright holder(s). The content must not be changed in any way or sold commercially in any format or medium without the formal permission of the copyright holders.

This document is the author's final version of the journal article. Some differences between the published version and this version may remain and you are advised to consult the published version if you wish to cite from it. 


\title{
Getting the Message Across for Safer Self-Recovery in Post- Disaster Shelter
}

\author{
Charles Parrack, Bill Flinn, Megan Passey
}

\begin{abstract}
Self-recovery in post-disaster shelter is not the exception but the norm. Following earthquake, flood or storm, the majority of affected families will inevitably rebuild their homes themselves, using their own resources, but there is little support from the international community to encourage good safe building practice.

While the communication of key messages about safer building has been carried out effectively in development contexts, it rarely forms a major part of humanitarian response programming. If the humanitarian shelter sector is committed to the principles of Disaster Risk Reduction (DRR), more can be done to support the process of safer reconstruction among self-rebuilders.

This paper argues the case for the humanitarian community to link post-disaster shelter programming with the more developmental approach of communicating building safety to a much wider audience than just the most vulnerable beneficiaries. It proposes the shelter sector and the donor community direct more resources towards support for this process, which it argues would augment the effectiveness and impact of a shelter response.
\end{abstract}

Key Words: self-rebuilding, building for safety, post-disaster reconstruction, post-disaster shelter, early recovery

\section{INTRODUCTION}

This paper is concerned with promoting safer reconstruction amongst families rebuilding their homes after a natural disaster. "Safety" refers to building techniques and practice that make buildings more able to resist hazards such as flood, earthquake and severe storm. As the focus is on safer construction, the list of hazards does not include those better dealt with by site selection and planning such as landslide, fire and volcano.

Self-recovery can imply self-build but also can also include rebuilding using the local informal building sector. Either way, households rebuild or repair damaged or destroyed homes using their own assets. Assets can be savings, materials (salvaged, donated or owned), social and community assets, local skills and labour. Increasingly, remittances from family members living abroad are an important asset. ${ }^{1}$

Faced with the impossibility of providing shelter assistance to all families post-disaster, beneficiary selection is often tailored to assist the most vulnerable. An unintended consequence can be that the majority who self-build incorporate the same bad building practice that caused their

\footnotetext{
${ }^{1}$ According to the 2013 Multilateral Investment Fund report on Remittances to Latin America and the Caribbean (Maldonado and Hayem, 2013) "almost USD\$2 billion flowed into Haiti in the form of remittances in 2012
} 
home to be damaged in the first place. The recent disasters in Haiti and the Philippines both provide ample examples of construction that ignores best practice and simple safety features.

This paper investigates the level of engagement of the humanitarian community with selfrebuilders and addresses risk management in this process. With reference to recent responses, it explores and analyses shelter programmes that include the promotion of messages about safer building to self-rebuilders, and presents the case for a change of emphasis that will increase the impact and effectiveness of a humanitarian response.

\section{THE CASE FOR SUPPORTING SELF-RECOVERY}

There are two particularly compelling arguments for supporting self-recovery: first, it is evident that the majority of houses destroyed by storm, flood or earthquake are re-built by the families themselves using their own resources; and second, if the international response continues with conventional product-based responses such as transitional and permanent shelter, it will not meet a significant proportion of the need with a solution that is long term, high quality and safe. Neither realisation is new, as pointed out by lan Davis over 30 years ago: "... the vast majority of all low income small dwellings are owner built within the 'informal sector', and are likely to remain so, we have to ask what impact can be made on future housing" (Davis, 1981); and by the 2011 Humanitarian Emergency Response Review: "Providing adequate shelter is one of the most intractable problems in humanitarian response" (Ashdown, 2011). In very stark terms, this implies that many houses built after an earthquake, storm or flood incorporate the same inadequate building practices that caused so much death, injury and economic damage in the first place.

The strongest case for supporting self-recovery is the recognition that it is an inevitable process. A discussion of the scale and complexity of shelter responses is continued below, but the assertion can be illustrated and explained using the 2010 Haiti earthquake as an example. The shelter practitioner standing amongst the rubble of Port-au-Prince a few weeks after the earthquake could have pointed out, with some degree of certainty, that the majority of the city's houses would be rebuilt by the Haitian informal sector and would be made from stone, reinforced concrete and hollow concrete blocks. Despite the subsequent efforts of engineers, architects and donors the prediction proves to be correct ${ }^{2}$. The exposition of over 60 designer houses at Zoranje on the outskirts of Port-au-Prince is an embarrassment of empty and inappropriate one-off prototypes that was opened with great fanfare and supported by the Bill Clinton Foundation. Intended as a demonstration site, a kind of marketplace for housing solutions, it remains a folly of unsuitable (and empty) homes. Another example of inappropriate housing is the nearby Morne a Cabri, a site of 3,000 identical concrete cubes that appear to have been built without consideration of basic services, employment opportunities or transport links. By comparison it was estimated by mid-2012 that 130,000 permanent homes had been rebuilt by Haitians themselves.

The international community did provide, over three years, around 113,000 temporary homes (referred to as t-shelters) for destitute families (IFRC, 2011). This is no small feat under the circumstances as materials had to be imported, land secured, designs approved, beneficiary families identified and contracts awarded. The fact remains, however, that these one-room buildings have a life span of three to five years and cost on average over US\$4,000 each (Beunza and Eresta, 2011). Many were built to very low construction and engineering standards that would not withstand hurricane-force storms. These buildings, as they deteriorate, will either be replaced by owner-built houses or will be extended and patched-up to become sub-standard and potentially dangerous permanent homes. Rather than a problem solved, this is a problem postponed. It will be the owners

\footnotetext{
${ }^{2}$ Some observers, for example Thummarukudy (2010), have pointed out that the inhabitants of Port-au-Prince initially were understandably reluctant to return to concrete homes for fear of another earthquake. This does not detract from the argument except to underline that in the world of post-disaster housing reconstruction nothing can be taken for granted.
} 
themselves, relying on their own resources, who will rebuild these t-shelters with little or no guidance on building more safely.

Haiti illustrates many of the problems facing humanitarian intervention. The earthquake killed in the region of 200,000 people and destroyed or damaged as many as 375,000 houses in the capital city of the poorest country in the hemisphere. It also wrecked the already weak government institutions. While the Haitian example is particularly extreme, every disaster is unique and direct comparisons are hard to find. Despite this, a brief overview of shelter responses from several recent disasters (see table) illustrates that the inability of the international community to make an impact on overall shelter needs within the first year is the norm and not the exception. 
Shelter Needs and Shelter Response for some Recent Emergencies

\begin{tabular}{|c|c|c|c|c|}
\hline $\begin{array}{l}\text { Emergency Name, } \\
\text { Date }\end{array}$ & Description & $\begin{array}{l}\text { No. } \\
\text { households } \\
\text { with shelter } \\
\text { needs }\end{array}$ & $\begin{array}{l}\text { No. of } \\
\text { transitionall } \\
\text { permanent } \\
\text { shelters built } \\
\text { within } 1 \text { year }\end{array}$ & $\begin{array}{l}\text { \% Shelter needs } \\
\text { met with } \\
\text { transitional or } \\
\text { permanent } \\
\text { shelter }\end{array}$ \\
\hline $\begin{array}{l}\text { Haiti Earthquake, } \\
\text { January } 2010\end{array}$ & $\begin{array}{l}\text { Around } 3.5 \text { million people were affected by the } 7.0 \\
\text { magnitude earthquake that struck Haiti's capital Port- } \\
\text { au-Prince in January } 2010 \text {. The epicentre was a } \\
\text { densely populated urban area with poor quality housing. } \\
\text { Much of this was severely damaged or destroyed and } \\
1.5 \text { million people were left homeless. } \\
\text { The emergency shelter response was swift, and there } \\
\text { was an extensive distribution of tarpaulins within } 4 \\
\text { months. The reconstruction phase however was much } \\
\text { slower and out of a palette of available options, many } \\
\text { agencies opted for transitional shelters. By July } 2013 \text {, } \\
\text { more than three years later, an estimated } 113,315 \\
\text { transitional and permanent shelters had been delivered, } \\
\text { reaching approximately 30\% of those with shelter } \\
\text { needs. } \\
\text { (IFRC, 2011); (Shelter Cluster, 2013) }\end{array}$ & 375,000 & 39,219 & $10.4 \%$ \\
\hline $\begin{array}{l}\text { Cyclone Sidr, } \\
\text { Bangladesh, } \\
\text { November } 2007\end{array}$ & $\begin{array}{l}\text { The number of homes damaged by cyclone Sidr was } \\
\text { four times greater than the number of homes affected } \\
\text { by the } 2005 \text { Pakistan earthquake, leaving almost } 1.5 \\
\text { million households without shelter. Less than five } \\
\text { months later, a joint government and United Nations } \\
\text { assessment estimated that three quarters of these } \\
\text { families had begun to rebuild on their own with no } \\
\text { external assistance. Shelter Cluster members voiced }\end{array}$ & $1,470,419$ & 14,200 & $<1 \%$ \\
\hline
\end{tabular}




\begin{tabular}{|c|c|c|c|c|}
\hline & $\begin{array}{l}\text { fears that without technical assistance, these families } \\
\text { were replicating the same unsafe building techniques. } \\
\text { By May } 2009 \text { the cluster reported that } 14,200 \\
\text { transitional and permanent shelters had been } \\
\text { completed. These met less than } 1 \% \text { of the total shelter } \\
\text { need and reached only around } 4 \% \text { of the most } \\
\text { vulnerable families considered incapable of rebuilding } \\
\text { on their own. } \\
\text { (Davidson, 2008) ; (Shelter Cluster, 2008) }\end{array}$ & & & \\
\hline $\begin{array}{l}\text { El Salvador Floods } \\
\text { and Landslides, } \\
\text { October \& } \\
\text { November } 2009\end{array}$ & $\begin{array}{l}\text { Tropical Depression 12-E caused heavy rainfall and } \\
\text { storms in October and November } 2009 \text {, which led to } \\
\text { extensive flooding and landslides in El Salvador. An } \\
\text { estimated } 300,000 \text { people were affected and thousands } \\
\text { of homes damaged or destroyed. The Shelter Cluster } \\
\text { was activated for only a three month period, November } \\
\text { to January, during which it agreed on a model for } \\
\text { temporary housing and was able to deliver over } 1,000 \\
\text { units. By the time the Shelter Cluster handed over to the } \\
\text { government of El Salvador in January } 2010 \text {, over } 55 \%\end{array}$ & 2,350 & $\begin{array}{l}>1,310 \\
\text { by Jan } 2010\end{array}$ & $\begin{array}{l}>55.7 \% \\
\text { by Jan } 2010\end{array}$ \\
\hline
\end{tabular}




\begin{tabular}{|l|l|l|l|}
\hline & $\begin{array}{l}\text { of households with shelter needs had received one of } \\
\text { these temporary shelters. However, the construction of } \\
\text { permanent homes took much longer and the first of } \\
\text { these were not completed until May 2010. } \\
\text { (Beúnza, 2011) }\end{array}$ & $\mathbf{4 5 0 , 0 0 0}$ & $\mathbf{1 3 , 0 0 0}$ \\
\hline $\begin{array}{l}\text { Cyclone Nargis, } \\
\text { Myanmar, May }\end{array}$ & $\begin{array}{l}\text { An estimated 2.4 million people were affected by } \\
\text { Cyclone Nargis in May 2008 and 1.4 million left } \\
\text { homeless. The initial emergency shelter response } \\
\text { prioritised the delivery of plastic sheeting, which was } \\
\text { provided to 53\% of affected households within two } \\
\text { months. The recovery phase focused on both shelter } \\
\text { construction and repair. In addition to the 13,000 } \\
\text { transitional and permanent shelters constructed within } \\
\text { one year, repairs had been carried out on an estimated } \\
\text { 30,000 damaged homes. } \\
\text { (Emergency Shelter Cluster, 2008), (Alexander, 2009); (Shelter Cluster, } \\
\text { 2009) }\end{array}$ & $\mathbf{2 . 8 \%}$ \\
& & \\
\hline
\end{tabular}


The percentage figures in each of the examples show that humanitarian organisations rarely reach more than thirty percent of the shelter needs within the first year after a major disaster, and some significantly lower, with single figures not uncommon. The vast majority therefore cope on their own, either self-building or using their own resources to obtain the services of local builders and tradesmen. The total figures show that the task of rebuilding to meet all shelter needs, or even a significant proportion of them, is well beyond the capacity of the aid community. ${ }^{3}$ What is not considered is whether messages about safer building are transmitted by agencies or received by beneficiaries. Since this is rarely measured, the lack of data makes it difficult to assess and is a limitation of this paper. We recommend that further research be carried out to determine the degree and efficacy with which messages on safer reconstruction are communicated to selfrebuilders.

The scale of the problem makes the task of building back safer, or making a significant impact on the safety of post-disaster self-recovery, seem challenging. The evidence shows that the task is likely to become more demanding. The number of climate related disasters (floods, storms and droughts) is steadily increasing. Since 1980, the number of floods has almost quadrupled and the number of storms has doubled (UNDSR, 2012). While the number of earthquakes remains constant, the number of quakes with significant death tolls has been increasing over the past centuries as population increases, cities expand and building materials become more dangerous. Earthquakes that will kill more than 10,000 people can now be expected to occur sixty times a century - more than one every other year. ${ }^{4}$

Most families rebuild using their own resources and this is the central reason for trying to shift the emphasis towards supporting the process of self-recovery. However there are several other advantages that should be persuasive. Professor lan Davis (2013) paraphrases the late Otto Koenigsberger, professor of the Development Planning Unit at University College London, by saying that "relief is the enemy of recovery". Davis expands on this to explain that we should avoid doing anything best left to the house owner, avoiding paternalism and dependence. The second guiding principle of the World Bank/GFDRR Safer Homes, Stronger Communities states: "reconstruction begins the day of the disaster. If traditional construction methods need to change to improve building safety, governments must be prepared to act quickly to establish norms and provide training. Otherwise, reconstructed housing will be no less vulnerable to future disasters than what was there before. .... Owners are almost always the best managers of their own housing reconstruction"(Jha et al., 2010). It is possible that aid, or the promise of aid, can delay the commencement of reconstruction. On the other hand support for self-recovery can start very quickly while any NGO-driven construction project has a long lead-in time while designs are agreed, land tenure assured, materials procured and builders contracted. This has never been more evident than in the recent Typhoon Haiyan in the Philippines (November 2013). Filipino families began cleanup and reconstruction immediately. At the time of writing, it is too soon to know if the shelter sector can respond effectively and rapidly to support families in rebuilding more safely.

Clinton (2006) provided ten defining propositions that led to an increase in 'build back better' initiatives and programmes after the 2004 Indian Ocean tsunami. Kennedy et al. (2008) point out the risks of misinterpreting the word 'better' which was understood by beneficiaries to mean masonry because it was modern and represented progress. Kennedy and his co-authors proposed renaming the initiative 'Build Back Safer' to avoid confusion and reflect more accurately what the principles were designed to support.

Risk management is an understandable concern for NGOs undertaking shelter programmes. The appeal launched after the Indian Ocean tsunami of 2004 raised a quantity of money unequalled before or since. Agencies with no previous experience of shelter and no internal capacity took on

\footnotetext{
${ }^{3}$ To put this in perspective, the entire UK building industry built some 108,000 houses in 2012. (Department for Communities and Local Government 2013)

${ }^{4}$ Information from Dr John Elliott, Department of Earth Sciences, Oxford University (Elliott, 2011)
} 
substantial housing programmes. Many got their fingers burnt and the spectre of the tsunami still casts a shadow over the shelter community. Houses had to be rebuilt or strengthened retrospectively because they were shown to be designed without taking the considerable seismic risk into account (Da Silva, 2010) Shelter has often been considered a risky undertaking; the tsunami exacerbated that belief. The difficulties experienced by INGOs working on post-tsunami projects were not unique: there are other examples of failed and troubled shelter projects (for example Saunders 2004, Sanderson, Sharma and Anderson, 2012) Although shelter is recognised as an essential human right and a key component of recovery, many NGOs understandably steer clear because of their own lack of experience and the evident risks. The danger of designing and building an inappropriate house is only one aspect of risk: the house could also be badly engineered or badly constructed; it could be built on illegal land; it could be built on a site that subsequently floods. For others, the transitional shelter may be a more risk-free route. If the shelter is sub-standard, somewhat inadequate or under-engineered for the prevailing hazards, it does not matter quite so much because the building, after all, is only temporary.

By contrast, supporting self-recovery removes much of the risk from the compass of the relief agency and places it with the decision-maker, the house-owner. It is a fundamental of risk management that the risk should be borne by those best placed to do so, but this is often not the case in shelter programming. While it is incumbent on the NGO providing technical support to give good advice and to encourage safe practice in construction and choice of site, the ultimate decision rests with the family concerned. Frequently we are unable to support families that live on dangerous or illegal land but equally frequently those families have no choice: they don't want to live there, they are probably aware of the dangers, but their circumstances allow for no other option.

Supporting them in the construction of their own dwellings might help reduce the inherent danger.

An important caveat is due at this point. Supporting families in their own decisions about where and how to build does not remove a duty of care from the agency involved. Assisting families that live in precarious circumstances should never be seen as endorsing unsafe building on dangerous sites. However, creative ways need to be found to support the most at-risk families living in the most precarious conditions. Too often, for example as in the case of landless families living on government-owned kash land in Bangladesh, the most vulnerable are passed over because they are on unsafe or illegal sites.

A decision to support self-recovery does not preclude other forms of shelter assistance. A nuanced response might include some t-shelters where needed, some cash support for repair and rebuild, perhaps some rental support. Self-recovery can also overlap with owner-driven reconstruction programmes, community driven reconstruction, Build Back Better programmes and aided self-help programmes. A small construction programme of permanent houses for the most vulnerable families could form the training programme for local builders. As always each disaster has its own characteristics; no two are ever the same; and there are no simple answers.

Many international NGOs are now seeing cash transfer projects as an effective way of delivering relief to disaster affected families in a way that is speedy and efficient as well as supporting and stimulating local markets (for example Creti and Jaspars, 2006). A shelter programme that combines conditional cash transfer with support for self-recovery could result in rapid reconstruction as well as safer building practice. Cash transfer, training and technical support for building safety are obvious bed-fellows. Cash programmes coupled with technical support also enhance the family's freedom to choose and direct the progress of recovery. A delightful example of this is a major international NGO's cash transfer programme in West Sumatra following the 2009 Padang earthquake. Three and a half thousand houses were built by the families themselves, each one different and tailored to their individual needs and means. The sense of pride is clear in the personal touches of each house, the well tended gardens and verandas (Ashmore, 2012).

\section{DO SHELTER PROGRAMMES SUPPORT SAFER SELF-RECOVERY?}


In the series of shelter case studies (Ashmore, 2008, 2010, 2012, \& 2013) a total of 108 shelter projects are presented in four volumes: the most comprehensive collection of shelter case studies available in the sector. A survey of the case studies shows that while many include some element of DRR, only a minority demonstrate support for safer self-rebuilding as part of a shelter programme, and only one case study is concerned with communication and messaging as the central theme.

While many post-disaster shelter programmes have a building safety component, this is often very limited in scope with very few studies available to assess impact. Some exceptions are mentioned below, for which the dissemination of good building practice was a central pillar.

The first example is from Haiti where one of the many problems faced during reconstruction was the poor quality of locally available concrete blocks. Following the 2010 earthquake, Build Change invited suppliers in Port-au-Prince to participate in training on how to improve the quality of the building materials they produced. Participants were taught how to improve the compressive strength of the blocks through a range of different techniques. Some required no additional investment at all, such as mixing more thoroughly and prolonging the mechanical compression period. Other recommendations required some additional investment, such as adjusting the proportions of the materials in the mix and increasing curing time. Improvements in quality were considerable: after training, one supplier was able to increase the compressive strength of his blocks from 4 to $14.36 \mathrm{MPa}$, twice the minimum recommended strength for an earthquake zone. For this supplier, improved quality led to improved demand, allowing him to expand his business and increase production from 300 to 2,000 blocks per day (Build Change, 2012).

Larger scale examples of implementing programmes for building safety which have had an impact on self-rebuilders include the SEEDS Masons' Association, founded in response to the Gujarat earthquake of 2001, which turned into an 800 member organisation organising peer to peer training (UNISDR, 2007). More recently the One Room Shelter programme in Pakistan, in response to the 2010 floods trained over 200,000 people in safer building techniques (IOM Pakistan, 2014)

While still the exception rather than the norm, there are other examples in which the impact of safer building programmes has been assessed. An Education for Safe Building programme was run by a consortium of NGOs including Oxfam and Concern after an earthquake in Yemen in 1982. The project was run for three years, and half of the 638 affected villages were visited by a mobile unit providing training in safer construction. Almost a quarter of region's builders, 820 in total, were trained. An evaluation found that $84 \%$ of the homes built by trainees used improved building techniques, despite the extra cost (Benson, Twigg and Myers, 2001).

In 2010, Development Workshop France (DWF) carried out an impact assessment to evaluate a typhoon damage prevention project in central Vietnam, implemented by DWF over a ten-year period. The study examined contemporary construction in five communes in Thua Thien Hue province, which is vulnerable to annual typhoons and flooding (Norton and Chantry, 2010).

DWF's project activities included training local builders in safer construction techniques, raising awareness among families about the importance of prevention, and providing small loans for house strengthening. The assessment found that although many new homes remained vulnerable to floods and typhoons, there was a greater awareness of risk, and an increased use of safer construction methods in communes where DFW had worked for a long time. It concluded that households in these areas "tend to build their houses with stronger materials and better structures" compared to in areas where DFW had worked for fewer years or none at all. In general the study found that safe construction principles and techniques promoted by DWF had been applied "relatively widely" and were seen as effective methods of preventing typhoon damage by community members, builders and local government staff (Norton and Chantry, 2010).

The findings of this study highlight the importance of reinforcing messages about safer building over time-something very difficult to do in a post disaster context where humanitarian actors are unlikely to stay for long. Effective involvement of national authorities and development actors to 
support safer building initiatives in the long term is vital to ensure that messages, both post-disaster and developmental, are not forgotten.

These examples show that support for self-recovery is not new. Indeed, most agencies recognise the need to embed DRR into all their programmes including in those shelter projects that are dominated by construction. However there is a lack of evidence that efforts in training and communicating are having a significant impact on post-disaster recovery. The examples cited above demonstrate that some shelter programmes already contain elements of support for safer rebuilding. However, the extent of the success of these programmes is difficult to ascertain as there are few impact studies. The Development Workshop study suggests that support for safer selfrebuilding can take many years to bear fruit. The challenge to the humanitarian shelter sector is to build on the work already done, particularly by developmental agencies, to find effective ways of promoting incremental improvements that will significantly improve the safety of houses built by self-builders or the informal sector.

\section{BUILDING FOR SAFETY OR SAFER BUILDING?}

Any improvements in building practice have to be affordable. They also need to make the structure significantly safer, and must take existing building practice as the point of departure. The concept of incremental improvement is based on what we know, or what we can assume with a high degree of certainty, will be the materials and techniques that families will employ as they begin to rebuild their homes. The shelter practitioner mentioned at the outset of this paper, standing in the rubble of Port-au-Prince, knew that the city would be rebuilt in masonry; if she was in Myanmar it might be timber; in rural Peru it would surely be adobe.

There is an important distinction to be made between "safe" and "safer". Clearly the safer, the better, but some degrees of safety cannot be achieved. Designing against landslides and tsunamis is not feasible and the term "earthquake-proof" is unhelpful as well as un-achievable. In the realm of self-build, or building through the informal sector, where codes are not enforced and guidelines are simply guidelines and no more, then an argument has to be made for shifting the culture of building practice towards incremental changes that are easily understood and replicable and that make for safer buildings. Here we are mainly concerned with making houses that are less likely to cause death, injury or ruinous economic loss. To rebuild safer would be a great advance; to rebuild entirely safely remains an aspiration.

Any discussion on safer building practice has to happen alongside a debate about all aspects of appropriate design, especially the importance of a participatory process. There are examples of housing projects that may have been engineered to withstand a major earthquake but have been less than satisfactory to live in because they have not considered cultural appropriateness, comfort and adaptability (for example Sanderson, Sharma and Anderson, 2012).

\section{EXAMPLES OF SAFER BUILDING PRACTICE}

There are many simple and affordable ways in which small domestic buildings can be made safer. A few examples might help to appreciate the kind of improvements that can be simply communicated to homeowners and self builders in the informal sector.

One example is simplicity of design. It is not immediately apparent, for instance in an earthquake zone, why a building that is rectangular in plan is better than an L-shape, but this is a lesson that can be easily communicated and learnt. Another design detail to avoid is having the doorway immediately adjacent to a corner. It could also be an idea to consider two doors so that escaping from a building is easier. A building is stronger if the openings are in the long wall and 
avoided in the short wall. These are all design decisions that cost little or no money but can make a building safer. They are also simple messages to communicate.

In a timber frame building the hurricane strap is simple and cheap. This is a thin strip of metal nailed across a joint that makes it several times stronger than a normal nailed connection. The metal ties can be snipped from inexpensive galvanised metal sheet available the world over. This technique was widely adopted in the construction of transitional shelters in Haiti, but frequently applied incorrectly. A simple orientation on the correct application of hurricane strapping would have improved the strength of the shelters and avoided the time and money wasted in doing it wrong.

Most builders know that a ring beam is an important element in increasing the strength and safety of a concrete building. However its strength relies on the quality of the reinforced concrete. There are simple messages that can be communicated on the correct bending, tying and lapping of steel bars and the correct way to mix and pour concrete to avoid honeycombing (where the steelwork is exposed and will rapidly corrode) and ensure strength and durability.

These are just three examples of safer building practice that can be communicated in a straightforward manner. Moreover, they show that these messages might fall into the categories of design, materials and skills. There are many others that are specific to context, hazard, local vernacular building typologies and indigenous skills. Other messages, such as the design principles mentioned above, can be considered to be general good building practice applicable in many circumstances. Currently there is a lack of consensus on the relative priority and impact of different good construction messages and a lack of methodologies for successful communication strategies. However there is a growing consensus that getting these messages across, and ensuring that they are implemented, is an important step towards improving building safety and improving the longterm resilience of hazard-prone communities.

\section{CHALLENGES AND BARRIERS}

In this paper we argue for more emphasis on support for the inevitable process of self-recovery. There are several counter-arguments and by considering a few of them here we are recognising that they need to be carefully taken into account. Furthermore, no two disasters are ever the same and there are no blueprints or standard solutions.

There will always be a need to balance the immediate needs of homeless people with longerterm support for recovery. The case for the t-shelter is that it bridges a gap between the emergency and recovery or reconstruction. By supporting self-builders in the construction of permanent homes we are open to the criticism of condemning families to longer in tents or t-shelters. There may be some truth in this - the construction of a permanent home is never a quick process - but it is also interesting to note that the cost of a permanent house is sometimes not that much higher than the cost of a temporary t-shelter (Davis, 2012). Transitional shelters do also have a habit of becoming post facto permanent, but sub-standard and unsafe. The provision of transitional shelters in large numbers is also very expensive and according to evidence from Haiti, the community itself does not necessarily put housing as the top priority (Rule, 2013) ${ }^{5}$. If infrastructure and livelihoods are restored then houses may naturally follow - and support for that self-build process, while still imperative, comes at a lower cost.

Changing the attitude of donors and international agencies is another challenge. As one shelter practitioner stated: "donors required concrete numbers of beneficiaries and shelters [which] doesn't really promote the idea of working through a medium of information to assist the larger affected populations". Donors like solutions that are easy to count and have a clear beneficiary list; trainings,

\footnotetext{
${ }^{5}$ The British Red Cross found that a Haitian community ranked housing ninth in order of priority. From a presentation by Amelia Rule, BRC, to the UK Shelter Forum September 2013 (Rule, 2013).
} 
mass-messaging, and informal support to local builders are all difficult to clearly quantify. There may be a need for long term project support for safer self-rebuilding in order to make an impact, which may encounter funding and institutional support barriers. Undeniably, there is also a capacity and skills gap within the sector. The shelter practitioner with humanitarian experience, knowledge of effective communication techniques as well as sound construction and engineering skills is a rare breed in a world of increasing need. If effective communication of safer building strategies should become a key component in reconstruction programmes, the necessary skills will need to be encompassed by the practitioner or the shelter team.

\section{CONCLUSION}

Throughout this paper we have referred to the "inevitable" process of self-recovery. We argue that this process requires the shelter sector and the donor community to redirect resources towards support for this process. Failing to do so has a consequence: it runs the risk that the post-disaster reconstruction of houses will incorporate the same unsafe practice that caused so much damage in the first instance. We show that current shelter practice, particularly in major disasters, rarely provides for the needs of the majority, sometimes covering less than ten percent of the housing loss within the first year. Furthermore, this is often in the form of temporary one-room shelters. Consequently we conclude that the majority of permanent dwellings are built using the owner's own resources, either through self-build or using the informal building sector. This provides an opportunity, as well, arguably, as a moral obligation, to augment the effectiveness and impact of a shelter response through increased support for the process of self-recovery. This does not imply a complete volte face; all shelter responses are complex and varied and the process of improving safety as part of self-recovery fits well with cash transfers, livelihood programmes, integrated neighbourhood projects and so on. Communication of safer construction techniques can also complement t-shelter, one-room-shelter, prototype model houses and other construction projects.

We have illustrated some successful examples of communicating good practice in both development and humanitarian settings. However, our research also shows that these examples are few and far between and that there is little evidence to show the effectiveness and impact of messaging, training and awareness-raising in a post-disaster scenario. To increase this impact and engender an understanding of safe building good practice, there has to be an increase in the relevant skills within the sector and reliable access to good, technical information.

There is never a one-size-fits-all solution to shelter programming. However there is a strong case to be made for placing much more emphasis on increasing the safety of owner-built housing. This will have a significant impact on the lives of many by reducing their risk to future hazards and encouraging a change across the community towards safer building practice.

\section{REFERENCES}

ALEXANDER, J. (2009) Emergency Shelter Cluster Review, Cyclone Nargis, Myanmar. IFRC, Geneva.

ASHDOWN, P. (2011). Humanitarian Emergency Response Review. Department for International Development, London.

ASHMORE, J. (2013) Shelter Projects 2011-2012. IFRC, UN-HABITAT and UNHCR, Geneva.

ASHMORE, J. (2012) Shelter Projects 2010. IFRC, UN-HABITAT and UNHCR, Geneva.

ASHMORE, J. (2010) Shelter Projects 2009. IFRC, UN-HABITAT and UNHCR, Geneva. 
ASHMORE, J. (2008) Shelter Projects 2008. UN-HABITAT, Geneva.

BENSON, C., TWIGG, J. \& MYERS, M. (2001) NGO initiatives in risk reduction: an overview. Disasters, 25(3), 199-215.

BEÚNZA, A. AND ERESTA, I. (2011) An Evaluation of the Haiti Earthquake 2010: Meeting Shelter Needs: Issues. Achievements and Constraints. IFRC, Geneva

BEÚNZA, A. (2011) A Review of the 2009 Tropical Storm Ida floods IFRC-led Shelter Cluster in EI Salvador. IFRC, Geneva

BUILD CHANGE (2012) Nicolas Chevelon Produces Better Blocks Available at http://www.buildchange.org/success haiti.html (Accessed: 04 February 2014)

CLINTON, W.J. (2006), Lessons Learned from Tsunami Recovery: Key Propositions for Building Back Better, United Nations Secretary-General's Special Envoy for Tsunami Recovery, United Nations, New York.

CRETÌ, P., and JASPARS, S. (Eds.). (2006). Cash-transfer programming in emergencies. Oxfam, Oxford.

DA SILVA, J. (2010). Lessons from Aceh. Key Considerations in Post-Disaster Reconstruction. Practical Action Publishing.

DAVIDSON, S. (2008) A Review of the IFRC-led Shelter Coordination Group Bangladesh Cyclone Sidr Response 2007-2008. IFRC, Geneva.

DAVIS, I. (1981). Disasters and the small dwelling. Pergamon Press, Oxford.

DAVIS, I. (2012). What is the vision for sheltering and housing in Haiti. Summary Observations of Reconstruction Progress following the Haiti Earthquake of January 12th 2010. ONU Habitat, Latin America

DAVIS, I. (2013) Shelter after disaster: quotes, do's don'ts and principles [lecture to MA Development and Emergency Practice] Oxford Brookes University, 25 February 2013.

DEPARTMENT FOR COMMUNITIES AND LOCAL GOVERNMENT (2013) House Building Statistics. Available at https://www.gov.uk/government/collections/house-building-statistics (Page Updated 21 November 2013)

ELLIOTT, J. (2011) Eathquakes and Faulting [lecture to MA Development and Emergency Practice] Oxford Brookes University, 23 March 2011

EMERGENCY SHELTER CLUSTER (2008) Strategic Framework Cyclone Nargis, 2008, Sheltercluster.org, Geneva

IFRC (2011) An Evaluation of the Haiti Earthquake 2010, Meeting Shelter Needs: Issues Achievements and Constraints. IFRC, Geneva 
IOM PAKISTAN (2014) One Room Shelter Program. Available at https://www.iom.int/jahia/webdav/shared/shared/mainsite/media/docs/reports/ORS-Booklet.pdf (Accessed 04 February 2014)

JHA, A. K., BARENSTEIN, J. D., PHELPS, P. M., PITTET, D., \& SENA, S. (2010). Safer homes, stronger communities. A handbook for reconstruction after natural disasters. The World Bank, Washington, DC

KENNEDY, J., ASHMORE, J., BABISTER, E., \& KELMAN, I. (2008). The Meaning of 'Build Back Better': Evidence From Post-Tsunami Aceh and Sri Lanka. Journal of Contingencies and Crisis Management, 16(1), 24-36.

MALDONADO R., HAYEM, M. (2013) Remittances to Latin America and the Caribbean in 2012: Differing behavior across subregions Multilateral Investment Fund,: Inter-American Development Bank, Washington, D.C

NORTON, J., AND CHANTRY, G., (2010) Impact Study on Developing Local Capacity to Reduce Vulnerability and Poverty in Central Vietnam Available at http://lauratest.drupalgardens.com/sites/lauratest.drupalgardens.com/files/DWF\%20Vietnam\%20p revent\%20housing\%20typhoon\%20damage\%20-\%20Impact\%20study\%20Final.pdf (accessed: 24/09/2013)

PAKISTAN EARLY RECOVERY SHELTER CLUSTER (2010) Pakistan Floods 2011 Early Recovery Framework. Available at http://pakresponse.info/Portals/0/Key_Docs/Pakistan\%20Early\%20Recovery\%20Framework\%20Flo ods\%202011_210212.pdf (Accessed 05 February 2014)

PAKISTAN EARLY RECOVERY CLUSTER (2011a) Floods 2010 Early Recovery Bulletin, Aug 2011. UNDP, Islamabad.

PAKISTAN EARLY RECOVERY CLUSTER (2011b) Pakistan Floods 2010 Early Recovery Final Report. UNDP, Islamabad.

RULE, A. (2013) Update from the British Red Cross [lecture to the UK Shelter Forum, September 2013] University College London.

SANDERSON, D., SHARMA, A., \& ANDERSON, J. (2012). NGO permanent housing 10 years after the Gujarat earthquake: revisiting the FICCI-CARE Gujarat rehabilitation programme. Environment and Urbanization, 24(1), 233-247.

SAUNDERS, G. (2004). Dilemmas and challenges for the shelter sector: lessons learned from the sphere revision process. Disasters, 28(2), 160-175.

SHELTER CLUSTER (2008) Shelter Cluster press release, 04/2008. Available at https://www.sheltercluster.org/Asia/Bangladesh/CycloneSidr2007/Documents/Press (Accessed 13 september 2013)

SHELTER CLUSTER (2009) Shelter Cluster Myanmar Key Messages, April 2009 UN Habitat Myanmar SHELTER CLUSTER (2013) Haiti Fact sheet July 2013. Available at http://reliefweb.int/report/haiti/ha\%C3\%AFti-fact-sheet-uclbp-cluster-abris-et-cccm-\%E2\%80\%93- 
juillet-

2013?utm source=buffer\&utm campaign=Buffer\&utm content=buffer 3478 f\&utm medium=twitte r (Accessed 13 September 2013)

THUMMARUKUDY M. (2010) Haiti Mission Report 20 January - 19 March 2010, United Nations Environment Programme Nairobi

UNISDR (2007) Building Disaster Resilient Communities Good Practices and Lessons Learned A Publication of the "Global Network of NGOs" for Disaster Risk Reduction Geneva.

UNDSR (2012) Number of Climate-related Disasters Around the World (1980-2011) factsheet. Available at http://www.preventionweb.net/files/20120613 ClimateDisaster1980-2011.pdf (Accessed 13 September 2013)

\section{Author's Addresses}

Charles Parrack, Bill Flinn, Megan Passey

Centre for Development and Emergency Practice

Oxford Brookes University

Gipsy Lane

Oxford

UK

cparrack@brookes.ac.uk

http://architecture.brookes.ac.uk/research/cendep/shelter.html 